\title{
Anurans of the Reserva Ecológica da Michelin, Municipality of Igrapiúna, State of Bahia, Brazil
}

\author{
Felipe Camurugi ${ }^{1}$, Tasso Meneses Lima ${ }^{1}$ Ednei de Almeida Mercês ${ }^{1} \&$ Flora Acuña Juncá $^{1,2}$ \\ ${ }^{1}$ Departamento de Ciências Biológicas, Universidade Estadual de Feira de Santana - UEFS, \\ Av. Transnordestina, s/n, Novo Horizonte, CEP 44036-900, Feira de Santana, BA, Brazil \\ ${ }^{2}$ Corresponding author: Flora Acuña Juncá, e-mail: florajunca@yahoo.com.br
}

CAMURUGI, F., LIMA, T.M., MERCÊS, E.A. \& JUNCÁ, F.A. Anurans of the Reserva Ecológica da Michelin, Municipality of Igrapiúna, State of Bahia, Brazil. Biota Neotrop. 10(2): http://www.biotaneotropica.org.br/ v10n2/en/abstract?inventory+bn02810022010.

\begin{abstract}
We studied the richness and distribution of anuran species on different breeding sites at the Reserva Ecológica da Michelin (13 $50^{\prime} \mathrm{S}$ and 39 $9^{\circ} 10^{\prime} \mathrm{W}$, approximately 90-400 m above sea level), Municipality of Igrapiúna, Bahia State, Brazil. The reserve includes fragments of Atlantic Rain Forest varying from 140 to 650 ha. Five types of environments were sampled: leaf litter inside forest fragments, streams inside forest fragments, dam on the edge of forest fragment, temporary pond inside forest, and temporary ponds inside banana and rubber groves along the eastern boundary of the reserve. We used active and passive sampling methods for surveys of amphibians, between March 2007 and December 2008. We captured 48 species distributed in 10 families (number of species in parentheses): Aromobatidae (1), Brachycephalidae (4), Bufonidae (2), Craugastoridae (1), Centrolenidae (1), Cycloramphidae (3), Hylidae (29), Leiuperidae (1), Leptodactylidae (3), and Microhylidae (3). Temporary ponds presented the highest number of species in reproductive activity (19 species in native forested areas, and 21 in plantation areas), while leaf litter presented the lowest (6 species). Two species were found in bromeliads (Phyllodytes melanomystax and P. luteolus). Twenty-two species were exclusive to fragments of forest, 11 were found only in anthropized areas (dam, and rubber and banana plantations) and 15 in both environments. Aplastodiscus cavicola and Dendropsophus giesleri had their geographic distribution extended to the State of Bahia. Phasmahyla timbo and Chiasmocleis cordeiroi known only from their type localities were found in the reserve.
\end{abstract}

Keywords: inventory, geographic distribution, breeding sites, baixo sul.

CAMURUGi, F., LIMA, T.M., MERCÊS, E.A. \& JUNCÁ, F.A. Anuros da Reserva Ecológica da Michelin, Município de Igrapiúna, Estado da Bahia, Brasil. Biota Neotrop. 10(2): http://www.biotaneotropica.org.br/ v10n2/pt/abstract?inventory+bn02810022010.

Resumo: Nós estudamos a riqueza e distribuição de espécies de anuros em diferentes locais de reprodução na Reserva Ecológica da Michelin (135 50' S e 39 $9^{\circ}$ 10' O, aproximadamente 90-400 m acima do nível do mar), Município de Igrapiúna, Estado da Bahia, Brasil. A reserva inclui fragmentos de Mata Atlântica, variando entre 140 a 650 ha. Cinco tipos de ambientes foram amostrados: serapilheira no interior dos fragmentos de mata, córregos no interior dos fragmentos de mata, represa na borda de um fragmento de mata, poça temporária no interior de fragmento de mata e poças temporárias em seringal e bananal ao longo da margem leste da reserva. Nós usamos métodos amostrais ativos e passivos para captura dos anfíbios, entre março de 2007 e dezembro de 2008. Capturamos 48 espécies distribuídas em 10 famílias (número de espécies entre parênteses): Aromobatidae (1), Brachycephalidae (4), Bufonidae (2), Craugastoridae (1), Centrolenidae (1), Cycloramphidae (3), Hylidae (29), Leiuperidae (1), Leptodactylidae (3), and Microhylidae (3). Nas poças temporárias foi registrado o mais alto número de espécies em atividade reprodutiva (19 em áreas de floresta e $21 \mathrm{em}$ áreas de plantações), enquanto a serapilheira apresentou o número mais baixo (6 espécies). Duas espécies foram encontradas em bromélias (Phyllodytes melanomystax e P. luteolus). Vinte e duas espécies foram exclusivas do interior dos fragmentos de floresta, 9 foram encontradas somente em áreas antropizadas (represa, seringais e bananais) e 15 em ambos os ambientes. Aplastodiscus cavicola e Dendropsophus giesleri tiveram suas distribuições geográficas estendidas para o Estado da Bahia. Phasmahyla timbo e Chiasmocleis cordeiroi, conhecidas somente para suas localidadestipo, foram encontradas na reserva.

Palavras-chaves: inventário, distribuição geográfica, locais de reprodução, baixo sul. 


\section{Introduction}

In the Neotropical region, the loss of habitat and the fragmentation of natural environments are consequences of extensive agriculture, among other causes (Whitmore 1997). Although little information is available on the distribution of organisms in cultivated environments, it is known that the richness and abundance of animal species are strongly influenced by the size and the surrounding natural environments (Bernnett et al. 2006). Regarding the Atlantic Rain Forest, such fragments play an important role in the conservation of biodiversity due to the high levels of endemism observed in this biome, currently threatened by the loss of habitat generated mainly by urbanization and agriculture (Morellato \& Haddad 2000).

In this context, the loss of natural resources is a significant concern with regard to the anuran fauna (Duellman 1999). The Atlantic Rain Forest houses approximately 400 species of anurans, which comprises almost $50 \%$ of all the species known to occur in Brazil (Silvano \& Segalla 2005, Haddad et al. 2008). Probably, such species richness is supported by the heterogeneity of environments and the variety of microhabitats found in that biome (Cardoso et al. 1989).

The availability of aquatic environments is crucial for the reproduction of most anuran species and the type of aquatic environment could determine their reproductive modes (Duellman \& Trueb 1986). In the reproductive period, anurans can use ponds, lakes, bogs, streams, and phytothelms, comprising 39 different reproductive modes, 27 of them found in the Atlantic Rain Forest (Haddad \& Prado 2005).

The southern coast of the State of Bahia is located within the Atlantic Forest Domain (Ab'Sáber 1977), one of the 25 world hotspots for biodiversity conservation (Myers et al. 2000) and divided into three political regions: "Baixo Sul" (14 municipalities), "Litoral Sul" (27 municipalities), and "Extremo Sul" (21 municipalities) (Secretaria ... 2010). Silvano \& Pimenta (2003) found 115 species in southern Bahia (which encompasses 107 municipalities in the definition they used), and Carnaval et al. (2009) observed a higher genetic diversity in the populations of this region when compared to populations of other parts of the Atlantic Rain Forest.

Publication of species lists has been fundamental for the understanding of the biodiversity and potentialities of Neotropical forests (Duellman 1999, Silvano \& Segalla 2005). Moreover, it is difficult to plan conservation strategies without the minimum knowledge regarding the local species composition (Santos 2003).

This study aimed to inventory the anuran species of the Reserva Ecológica da Michelin located in the Municipality of Igrapiúna, "Baixo Sul" of the State of Bahia, Brazil, mainly within potential breeding sites.

\section{Material and Methods}

\section{Study area}

The Reserva Ecológica da Michelin is located in the Municipality of Igrapiúna, State of Bahia, Brazil (13 ${ }^{\circ} 50^{\prime} \mathrm{S}$ and $39^{\circ} 10^{\prime} \mathrm{W}, 90$ to $383 \mathrm{~m}$ above sea level), in a region known as "Baixo Sul", $200 \mathrm{~km}$ South from the State capital city of Salvador. Rainfall occurs throughout the year and largely varies between years (K. Flesher, pers. comm.). Mean annual precipitation in the reserve over the last 10 years was approximately $2000 \mathrm{~mm}$, temperature ranged from 21.7 to $30.8{ }^{\circ} \mathrm{C}$, and air humidity between 80 and $85 \%$. During the study period intense precipitation occurred between February and May (rainy season) and low precipitations between October and January (dry season; Lima \& Juncá 2009).

The reserve comprises two fragments of Atlantic Rain Forest of 325 and 650 ha under different stages of regeneration. The major fragment is part of a 13.000 ha Atlantic Forest patch and the other one is the sum of three distinct but connected areas. Rubber (Havea brasiliensis), cacao (Theobroma cacao), and banana plantations (Musa sp.), and a mixed tree crop groves with some manioc are also part of the landscape. The following habitats were investigated:

Temporary ponds in forest fragments: two ponds were sampled. The largest pond had up to $50 \mathrm{~cm}$ depth, area of approximately $180 \mathrm{~m}^{2}$, and was surrounded by grass, shrubs, and $10 \mathrm{~m}$ high trees (Figure 1a). When fully filled with water (September and October 2007; June and July 2008) it presented muddy bottom, and when empty deposits of organic matter from leaf and plant decomposition. The smallest pond was located at the forest edge and was fully filled with water only in July 2008. It was surrounded by large trees and shrubs, presented sandy bottom, depth up to $25 \mathrm{~cm}$, and area of approximately $16 \mathrm{~m}^{2}$.

Temporary ponds in plantations: these were sampled in plantations of rubber trees ( shaded, $n=1$ ), banana (open area, $n=1$, Figure $1 \mathrm{~b}$ ), and abandoned or rarely used roads (shaded, $n=2$ ). The area and depth of the ponds varied from $3 \mathrm{~m}^{2}$ and $30 \mathrm{~cm}$ to $180 \mathrm{~m}^{2}$ and $70 \mathrm{~cm}$, respectively.

Streams: seven slow-flowing streams located inside the forest (Figures 1c, 1d). Bottoms always presented rocks and other elements varying from sand to mud. The deepest stream was up to $50 \mathrm{~cm}$ approximately, and width varied from 90 to $250 \mathrm{~cm}$. Portions from 25 to $100 \mathrm{~m}$ were sampled.

Permanent pond in open area: one artificial dam surrounded by grass and shrubs (Figure 1f), presenting muddy bottom, area of $600 \mathrm{~m}^{2}$, and up to $2 \mathrm{~m}$ depth.

\section{Specimens sampling}

Two to three researchers sampled the area by active and passive (pitfall traps) methods. Active methods were employed on two to
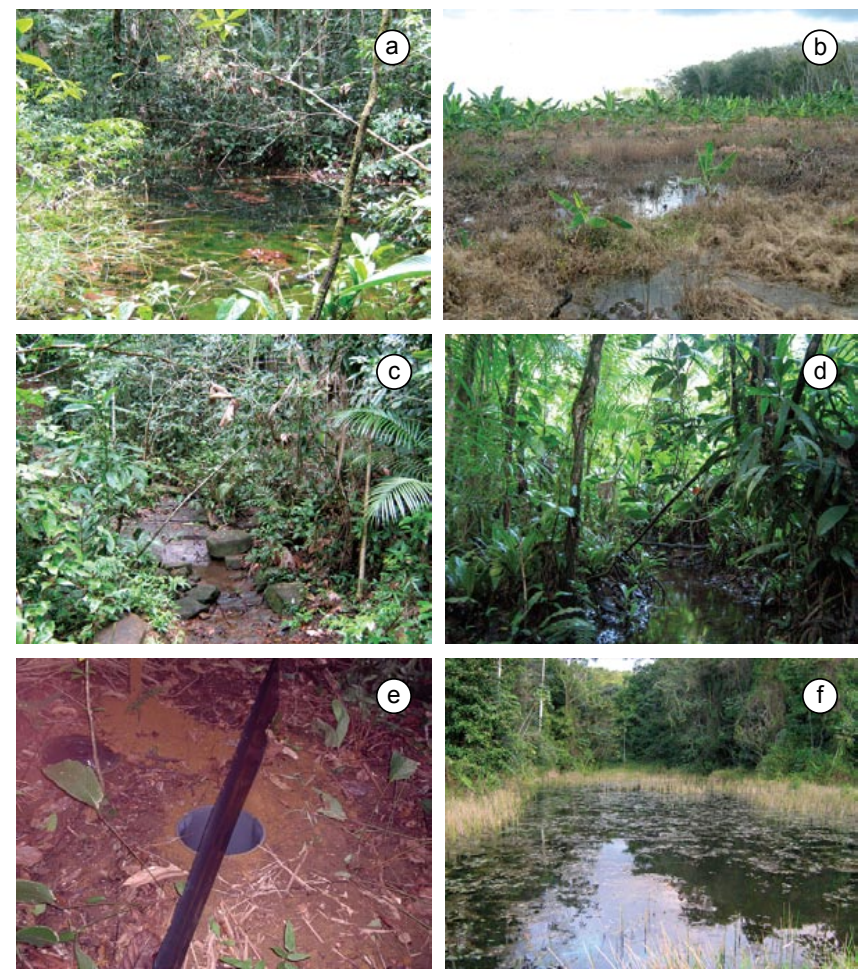

Figure 1. Sampled areas: a) temporary pond inside fragment forest; b) temporary pond in banana plantation; c-d) streams; e) pitfall trap in the forest; and f) dam in non-forested area. 
Table 1. Anuran species and their respective breeding sites at the Reserva Ecológica da Michelin, Municipality of Igrapiúna, State of Bahia, Brazil. LL - leaf litter, TP - temporary pond, PP - permanent pond, ST - stream, BR - bromeliad, FF - Fragment forest, RP - Rubber plantations, OA - Open area (banana plantation and dam).

\begin{tabular}{|c|c|c|c|c|c|c|c|c|}
\hline \multirow[t]{2}{*}{ Family/Species } & \multicolumn{5}{|c|}{ Habitat } & \multicolumn{3}{|c|}{ Environment } \\
\hline & $\mathbf{L L}$ & TP & PP & ST & BR & NF & $\mathbf{R P}$ & OA \\
\hline \multicolumn{9}{|l|}{ AROMOBATIDAE } \\
\hline Allobates olfersioides (Lutz, 1925) ${ }^{\dagger \mathrm{vU}}$ & - & - & - & $\mathrm{X}$ & - & $\mathrm{X}$ & - & - \\
\hline \multicolumn{9}{|l|}{ BRACHYCEPHALIDAE } \\
\hline Ischnocnema bilineata (Bokermann, 1975)* LC & $\mathrm{X}$ & - & - & - & - & $\mathrm{X}$ & - & - \\
\hline Ischnocnema paulodutrai (Bokermann, 1975) * LC & $\mathrm{X}$ & - & - & - & - & $\mathrm{X}$ & - & - \\
\hline Ischnocnema aff. ramagii & $\mathrm{X}$ & - & - & - & - & $\mathrm{X}$ & $\mathrm{X}$ & - \\
\hline Ischnocnema vinhai (Bokermann, 1975) ${ }^{\mathrm{LC}}$ & $\mathrm{X}$ & - & - & - & - & $\mathrm{X}$ & - & - \\
\hline \multicolumn{9}{|l|}{ BUFONIDAE } \\
\hline Rhinella crucifer (Wied-Neuwied, 1821) ${ }^{\mathrm{LC}}$ & - & $\mathrm{X}$ & - & - & - & $\mathrm{X}$ & $\mathrm{X}$ & - \\
\hline Rhinella hoogmoedi (Caramaschi \& Pombal, 2006) $)^{\dagger \mathrm{LC}}$ & - & - & - & $\mathrm{X}$ & - & $\mathrm{X}$ & $\mathrm{X}$ & - \\
\hline \multicolumn{9}{|l|}{ CRAUGASTORIDAE } \\
\hline Haddadus binotatus (Spix, 1824) ${ }^{\mathrm{LC}}$ & $\mathrm{X}$ & - & - & - & - & $\mathrm{X}$ & - & - \\
\hline \multicolumn{9}{|l|}{ CENTROLENIDAE } \\
\hline Vitreorana sp. ${ }^{\#}$ & - & - & - & $\mathrm{X}$ & - & $\mathrm{X}$ & - & - \\
\hline \multicolumn{9}{|l|}{ CYCLORAMPHIDAE } \\
\hline Macrogenioglottus alipioi (Carvalho, 1946) ${ }^{\mathrm{LC}}$ & - & $\mathrm{X}$ & - & - & - & $\mathrm{X}$ & - & - \\
\hline Proceratophrys renalis (Miranda-Ribeiro, 1920) ${ }^{\dagger \mathrm{LC}}$ & - & - & - & $\mathrm{X}$ & - & $\mathrm{X}$ & - & - \\
\hline Proceratophrys schirchi (Miranda-Ribeiro, 1937) ${ }^{\mathrm{LC}}$ & - & - & - & $\mathrm{X}$ & - & $\mathrm{X}$ & - & - \\
\hline \multicolumn{9}{|l|}{ HYLIDAE } \\
\hline Aplastodiscus cavicola (Cruz \& Peixoto, 1984) $)^{\dagger \mathrm{NT}}$ & - & - & - & $\mathrm{X}$ & - & $\mathrm{X}$ & - & - \\
\hline Aplastodiscus ibirapitanga (Cruz, Pimenta, \& Silvano, 2003) $)^{\dagger \mathrm{LC}}$ & - & - & - & $\mathrm{X}$ & - & $\mathrm{X}$ & - & - \\
\hline Aplastodiscus cf. sibilatus (Cruz, Pimenta, \& Silvano, 2003) \# & - & - & - & $\mathrm{X}$ & - & $\mathrm{X}$ & - & - \\
\hline Bokermannohyla capra ${ }^{\dagger \mathrm{DD}}$ (Napoli \& Pimenta, 2009) & - & - & - & $\mathrm{X}$ & - & $\mathrm{X}$ & - & - \\
\hline Dendropsophus branneri (Cochran, 1948) ${ }^{\dagger \mathrm{LC}}$ & - & $\mathrm{X}$ & $\mathrm{X}$ & - & - & - & $\mathrm{X}$ & $\mathrm{X}$ \\
\hline Dendropsophus elegans (Wied-Neuwied, 1824) ${ }^{\dagger \mathrm{LC}}$ & - & $\mathrm{X}$ & $\mathrm{X}$ & - & - & $\mathrm{X}$ & $\mathrm{X}$ & $\mathrm{X}$ \\
\hline Dendropsophus giesleri (Mertens, 1950) †DD & - & $\mathrm{X}$ & - & - & - & $\mathrm{X}$ & - & - \\
\hline Dendropsophus haddadi (Bastos \& Pombal, 1996) ${ }^{\dagger \mathrm{LC}}$ & - & $\mathrm{X}$ & - & - & - & $\mathrm{X}$ & - & $\mathrm{X}$ \\
\hline Dendropsophus minutus (Peters, 1872 ) $†$ LC & - & $\mathrm{X}$ & - & - & - & - & $\mathrm{X}$ & $\mathrm{X}$ \\
\hline Dendropsophus seniculus $(\text { Cope, } 1868)^{\dagger \mathrm{LC}}$ & - & $\mathrm{X}$ & - & - & - & $\mathrm{X}$ & - & $\mathrm{X}$ \\
\hline Dendropsophus sp. & - & $\mathrm{X}$ & - & - & - & $\mathrm{X}$ & - & - \\
\hline Hylomantis aspera (Peters, 1873$)^{\dagger \mathrm{LC}}$ & - & $\mathrm{X}$ & - & - & - & $\mathrm{X}$ & - & - \\
\hline Hypsiboas albomarginatus (Spix, 1824) $)^{\dagger \mathrm{LC}}$ & - & $\mathrm{X}$ & - & - & - & $\mathrm{X}$ & - & $\mathrm{X}$ \\
\hline Hypsiboas atlanticus (Caramaschi \& Velosa, 1996) ${ }^{\dagger \mathrm{LC}}$ & - & - & $\mathrm{X}$ & - & - & - & - & $\mathrm{X}$ \\
\hline Hypsiboas crepitans (Wied-Neuwied, 1824) LC & - & $\mathrm{X}$ & $\mathrm{X}$ & - & - & - & $\mathrm{X}$ & $\mathrm{X}$ \\
\hline Hypsiboas faber (Wied-Neuwied, 1821) ${ }^{\dagger \mathrm{LC}}$ & - & $\mathrm{X}$ & - & - & - & $\mathrm{X}$ & $\mathrm{X}$ & $\mathrm{X}$ \\
\hline Hypsiboas pombali (Caramaschi, Pimenta \& Feio, 2004) ${ }^{\mathrm{LC}}$ & - & $\mathrm{X}$ & - & - & - & $\mathrm{X}$ & $\mathrm{X}$ & $\mathrm{X}$ \\
\hline Hypsiboas semilineatus (Spix, 1824) ${ }^{\dagger \mathrm{LC}}$ & - & - & $\mathrm{X}$ & - & - & - & - & $\mathrm{X}$ \\
\hline Phasmahyla timbo Cruz, Napoli \& Fonseca, 2008 †D & - & - & - & $\mathrm{X}$ & - & $\mathrm{X}$ & - & - \\
\hline Phyllodytes luteolus (Wied-Neuwied, 1824) ${ }^{\mathrm{LC}}$ & - & - & - & - & $\mathrm{X}$ & $\mathrm{X}$ & - & - \\
\hline Phyllodytes melanomystax (Caramaschi, Silva \& Britto-Pereira, 1992) ${ }^{\mathrm{LC}}$ & - & - & - & - & $\mathrm{X}$ & $\mathrm{X}$ & $\mathrm{X}$ & - \\
\hline Phyllomedusa burmeisteri (Boulenger, 1882) & - & $\mathrm{X}$ & $\mathrm{X}$ & - & - & $\mathrm{X}$ & $\mathrm{X}$ & - \\
\hline Phyllomedusa nordestina (Caramaschi, 2006) & - & $\mathrm{X}$ & - & - & - & - & $\mathrm{X}$ & $\mathrm{X}$ \\
\hline Phyllomedusa rohdei (Mertens, 1926) ${ }^{\dagger \mathrm{LC}}$ & - & $\mathrm{X}$ & - & - & - & $\mathrm{X}$ & $\mathrm{X}$ & - \\
\hline Scinax aff. alter & - & - & $\mathrm{X}$ & - & - & - & - & $\mathrm{X}$ \\
\hline Scinax eurydice (Bokermann, 1968) ${ }^{\dagger \mathrm{LC}}$ & - & $\mathrm{X}$ & $\mathrm{X}$ & - & - & $\mathrm{X}$ & - & $\mathrm{X}$ \\
\hline Scinax strigilatus Pimenta, Faivovich \& Pombal Jr, 2007 DD & - & $\mathrm{X}$ & - & - & - & $\mathrm{X}$ & - & - \\
\hline Scinax $x$-signatus (Spix, 1824) & - & $\mathrm{X}$ & $\mathrm{X}$ & - & - & $\mathrm{X}$ & $\mathrm{X}$ & $\mathrm{X}$ \\
\hline Trachycephalus mesophaeus (Hensel, 1867) $)^{\dagger \mathrm{DD}}$ & - & $\mathrm{X}$ & - & - & - & - & $\mathrm{X}$ & $\mathrm{X}$ \\
\hline \multicolumn{9}{|l|}{ LEIUPERIDAE } \\
\hline Physalaemus signifer (Girard, 1853) ${ }^{\dagger \mathrm{LC}}$ & - & $\mathrm{X}$ & - & - & - & $\mathrm{X}$ & - & - \\
\hline \multicolumn{9}{|l|}{ LEPTODACTYLIDAE } \\
\hline Leptodactylus marmoratus (Steindachner,1867) ${ }^{\mathrm{LC}}$ & $\mathrm{X}$ & - & - & - & - & $\mathrm{X}$ & - & - \\
\hline Leptodactylus mystaceus (Spix, 1824) ${ }^{\dagger \mathrm{LC}}$ & - & $\mathrm{X}$ & - & - & - & $*$ & $\mathrm{X}$ & - \\
\hline Leptodactylus latrans (Steffen, 1815) ${ }^{\dagger \mathrm{LC}}$ & - & $\mathrm{X}$ & $\mathrm{X}$ & - & - & - & $\mathrm{X}$ & $\mathrm{X}$ \\
\hline \multicolumn{9}{|l|}{ MICROHYLIDAE } \\
\hline Chiasmocleis cordeiroi Caramaschi \& Pimenta, $2003^{\mathrm{DD}}$ & - & $\mathrm{X}$ & - & - & - & $\mathrm{X}$ & - & - \\
\hline Chiasmocleis sp. ${ }^{\dagger}$ & - & $\mathrm{X}$ & - & - & - & $\mathrm{X}$ & $\mathrm{X}$ & - \\
\hline Stereocyclops incrassatus (Cope, 1870) $)^{\dagger \mathrm{LC}}$ & - & $\mathrm{X}$ & - & - & - & $*$ & $\mathrm{X}$ & - \\
\hline Total number & 6 & 27 & 10 & 10 & 2 & 39 & 19 & 17 \\
\hline
\end{tabular}


four nights from August 2007 to July 2008, and in December 2008, lasting from five to eight hours each night. Specimens were sampled in forest fragments and cultivated areas, mainly near waterbodies, which represented breeding sites for most species. Tadpoles were sampled during the day in all types of waterbodies, in forested and non-forested areas. Species identification was based on part of a lot of the tadpoles collected, which was maintained in captivity in a plastic box with about $3 \mathrm{~L}$ of water, where they were fed on until metamorphosis was completed. One temporary and one permanent pond were monthly sampled between August 2007 and July 2008. Other places were sampled irregularly, with more effort during the wet periods.

In order to capture leaf litter frogs, eighty pitfall traps $(30 \mathrm{~L}$ plastic buckets with drift fence of $3 \mathrm{~m}$ long; Figure 1e) were installed inside two forest fragments at distinct areas from those of active sampling. Eight sampling units (SU) were placed at least $2 \mathrm{~km}$ from each other (three SU inside the 650 ha fragment and 5 in the 325 ha fragment). Each sampling unit contained 10 pitfall traps separated from each other by $10 \mathrm{~m}$ using an "L" design (the drift fence did not extend from one plastic bucket to other one). Such traps were kept active during 10 consecutive days in the months of March, May, July, September, and December 2007, totalizing an effort of 1200 hours (or 800 pitfall traps-night $\mathrm{x}$ excursion). All voucher specimens were deposited in the Museu de Zoologia da Universidade Estadual de Feira de Santana (MZUEFS) (Apendix 1).

\section{Results}

Forty-eight species distributed into 10 families were registered (Table 1). Among the species sampled by active methods $(\mathrm{n}=46)$, Vitreorana sp. (Centrolenidae) and Aplastodiscus cf. sibilatus (Hylidae) were captured exclusively in larval stages. Thirteen species belonging to 8 families were captured in the pitfall traps, all of them also captured by active methods, except by Ischnocnema paulodutrai and I. bilineata.

Among the habitats sampled by active methods, temporary ponds inside forest and plantations (rubber and banana) presented the highest number of species in reproductive activity (19 and 21 species, respectively), while leaf litter presented the lowest number (6 species). Two species were found in epiphytes and terrestrial bromeliads (Phyllodytes melanomystax and P. luteolus, Figures $2 \mathrm{j}$ and $2 \mathrm{k}$, respectively). Scinax $x$-signatus (Figure $2 \mathrm{~h}$ ) demonstrated high environmental plasticity, occurring in permanent and temporary ponds in open and forested areas (Table 1). On the other hand, 25 species were restricted to one type of habitat and environment (Table 1), of which only Hypsiboas atlanticus (Figure 2b), Hypsiboas semilineatus (Figure 2e), and Scinax aff. alter (Figure 31) occurred outside native forest. Twenty-two species were exclusively found inside the forest, 11 only in anthropized areas (open areas and rubber plantations) and 15 in both environments.

Among taxa identified to the specific level, 35\% are currently categorized as decreasing, $33 \%$ as stable, and $16 \%$ have their status of conservation unknown (International... 2009; Table 1).
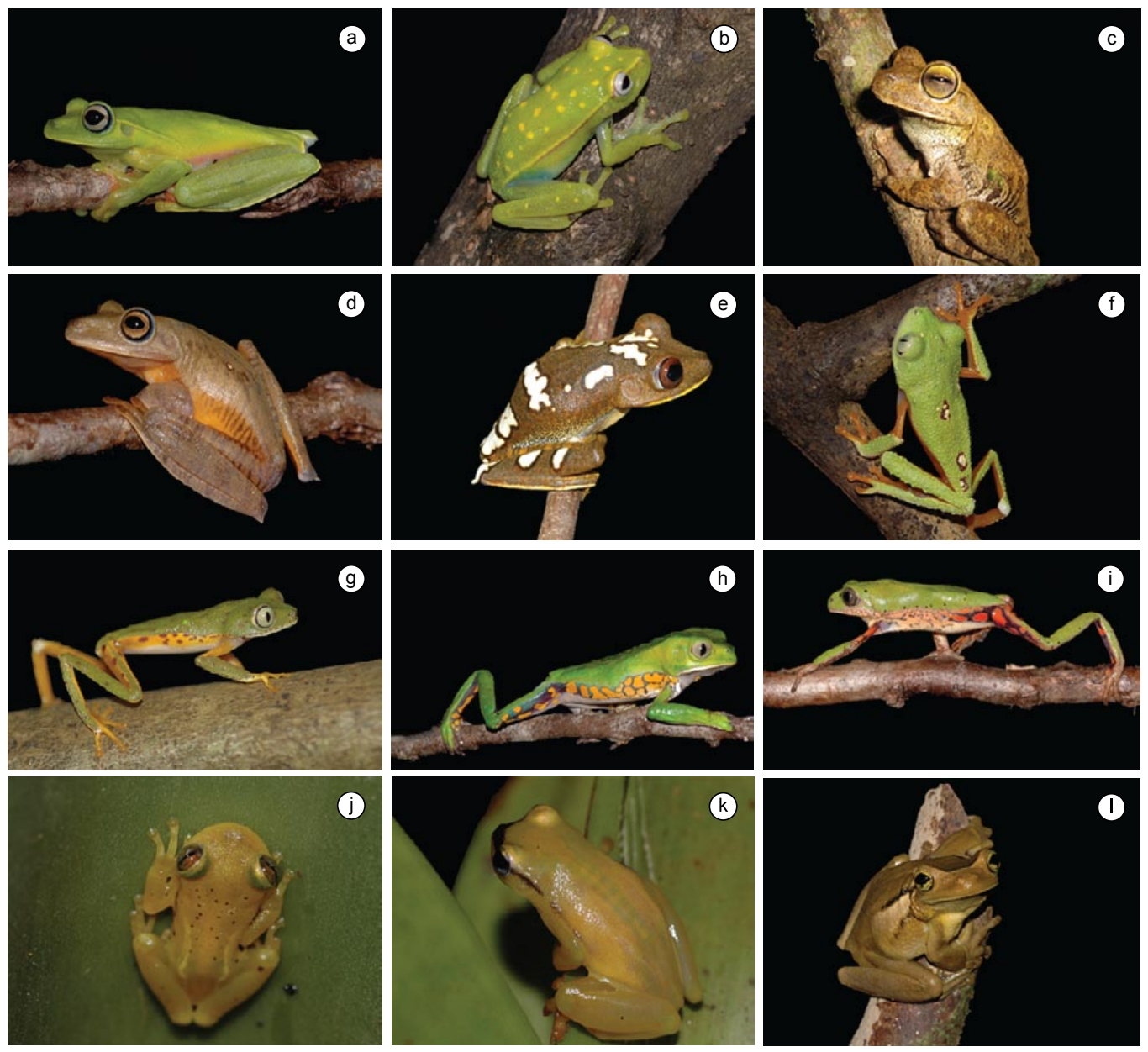

Figure 2. Anurans of the Reserva Ecológica da Michelin, Municipality of Igrapiúna, State of Bahia, Brazil. Hylidae: a) Hypsiboas albomarginatus; b) Hypsiboas atlanticus; c) Hypsiboas crepitans; d) Hypsiboas pombali; e) Hypsiboas semilineatus; f) Hylomantis aspera; g) Phasmahyla timbo; h) Phyllomedusa burmeisteri; i) Phyllomedusa rohdei; j) Phyllodytes luteolus; k) Phyllodytes melanomystax; and 1) Trachycephalus mesophaeus. 

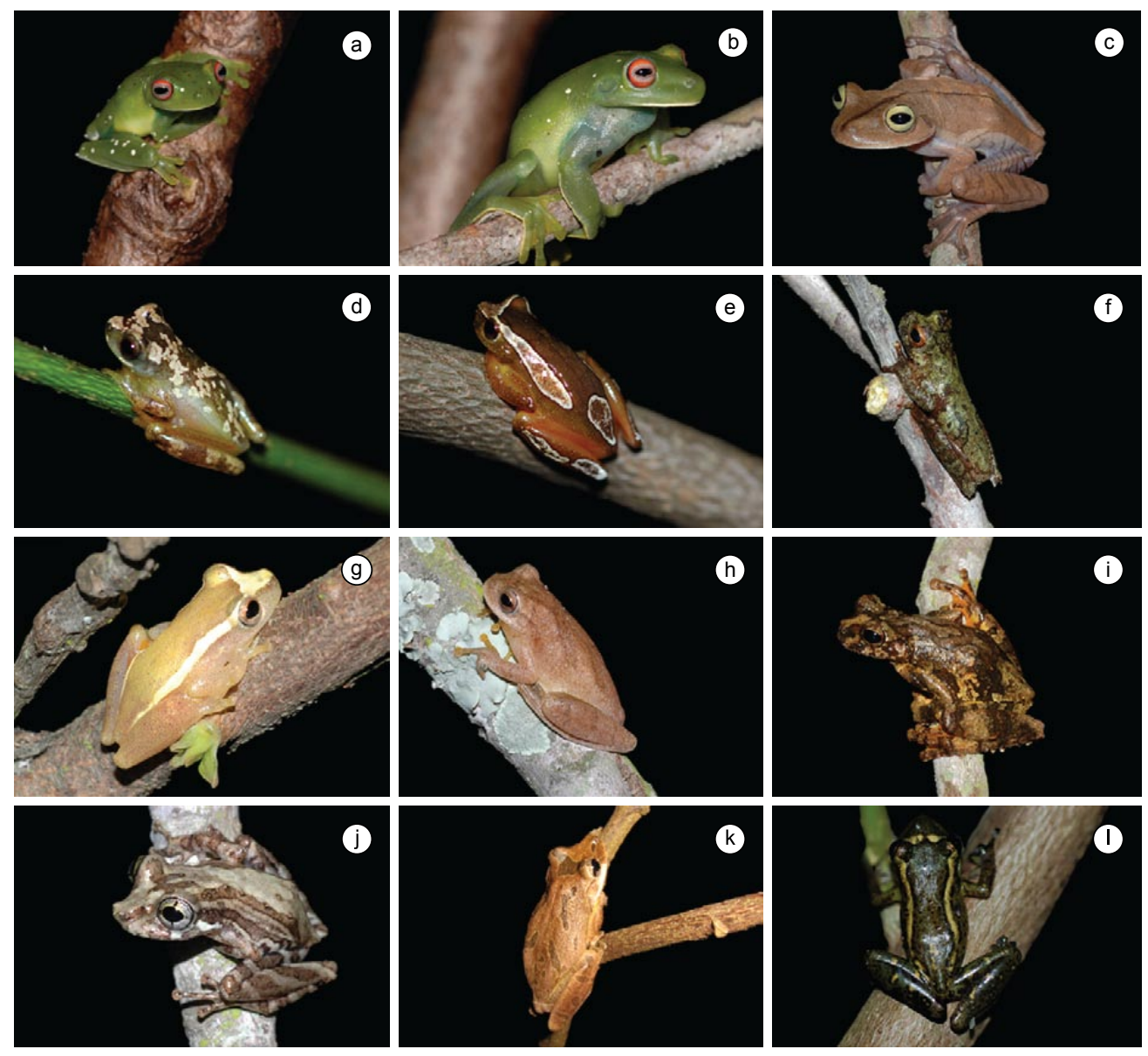

Figure 3. Anurans of the Reserva Ecológica da Michelin, Municipality of Igrapiúna, State of Bahia, Brazil. Hylidae: a) Aplastodiscus cavicola; b) Aplastodiscus ibirapitanga; c) Bokermannohyla capra; d) Dendropsophus branneri; e) Dendropsophus elegans; f) Dendropsophus giesleri; g) Dendropsophus haddadi; h) Dendropsophus minutus; i) Dendropsophus seniculus; j) Scinax strigilatus; k) Scinax eurydice; and 1) Scinax aff. alter.

\section{Remarks on Geographic Distribution}

Bokermanohyla capra (Figure 3c), Ischnocnema bilineata, I. paulodutrai, I. vinhai (Figure 4j), and Hylomantis aspera (Figure 2g) are endemic to the State of Bahia (Napoli \& Pimenta 2009, Juncá \& Pimenta 2004, Pimenta \& Juncá 2004, Peixoto \& Pimenta 2004, Silvano \& Pimenta 2004, respectively). Phasmahyla timbo and Chiasmocleis cordeiroi, also endemics to the Bahia State, were previously known only from their type localities in the municipalities of Amargosa (150 km North from Igrapiúna) and Camamu (14 km South from Igrapiúna), respectively. Aplastodiscus cavicola (Figure 2a) was known only for the States of Minas Gerais and Espírito Santo (Cruz et al. 2004), and Dendropsophus giesleri (Figure 2f) for the States of Espírito Santo, Rio de Janeiro, and São Paulo (Carvalho-e-Silva \& Telles 2004). The records of both species in the Municipality of Igrapiúna extend their distributions approximately 700 km Northwards.

\section{Discussion}

Silvano \& Pimenta (2003) studied 21 Atlantic Rainforest remnants in 19 municipalities from Southern Bahia and registered 115 species of anurans, a very expressive number, which correspond to almost $25 \%$ of the total anuran richness for the Tropical Atlantic Forest (Haddad et al. 2008). Among the localities they sampled, the area with the highest species richness was the Reserva Particular do Patrimônio Natural (RPPN) Estação Veracel (formerly RPPN Estação Veracruz; see Pimenta et al. 2007), Municipality of Porto Seguro, with 39 species. In that work, the sampled localities closer to the Reserva Ecológica da Michelin are situated in the municipalities of Cairu, Nilo Peçanha, and Camamu, where they found 18, 23, and 32 species, respectively. Although species richness were smaller than that found at Igrapiuna, the sum of these three localities results in 40 species, a number close to that observed at the Reserva Michelin. It is important to note that the sampling developed by Silvano \& Pimenta (2003) lasted four nights in each of these fragments and only active searches were used. Also, the habitats investigated in Cairu were represented mainly by arboreal "restinga" (see Pimenta et al. 2009), an habitat very distinct from those found at the Reserva Ecológica da Michelin. Thus, the larger number of species found at the Reserva Ecológica da Michelin possibly is the result of the larger effort on active searches, the use of pitfall traps, and the different habitats and environments sampled. Even so, many species found in the localities sampled by Silvano \& Pimenta (2003) were not found at the Reserva da Michelin and vice-versa, showing that when we consider the anuran richness of this region as a whole, levels of diversity and endemism are very high.

The high number of anuran species $(n=35)$ occurring in only one type of breeding site (temporary ponds) is related to the reproductive modes of these species, which limit the use of some habitats and microhabitats (Bertoluci \& Rodrigues 2002). Based on the tadpoles 

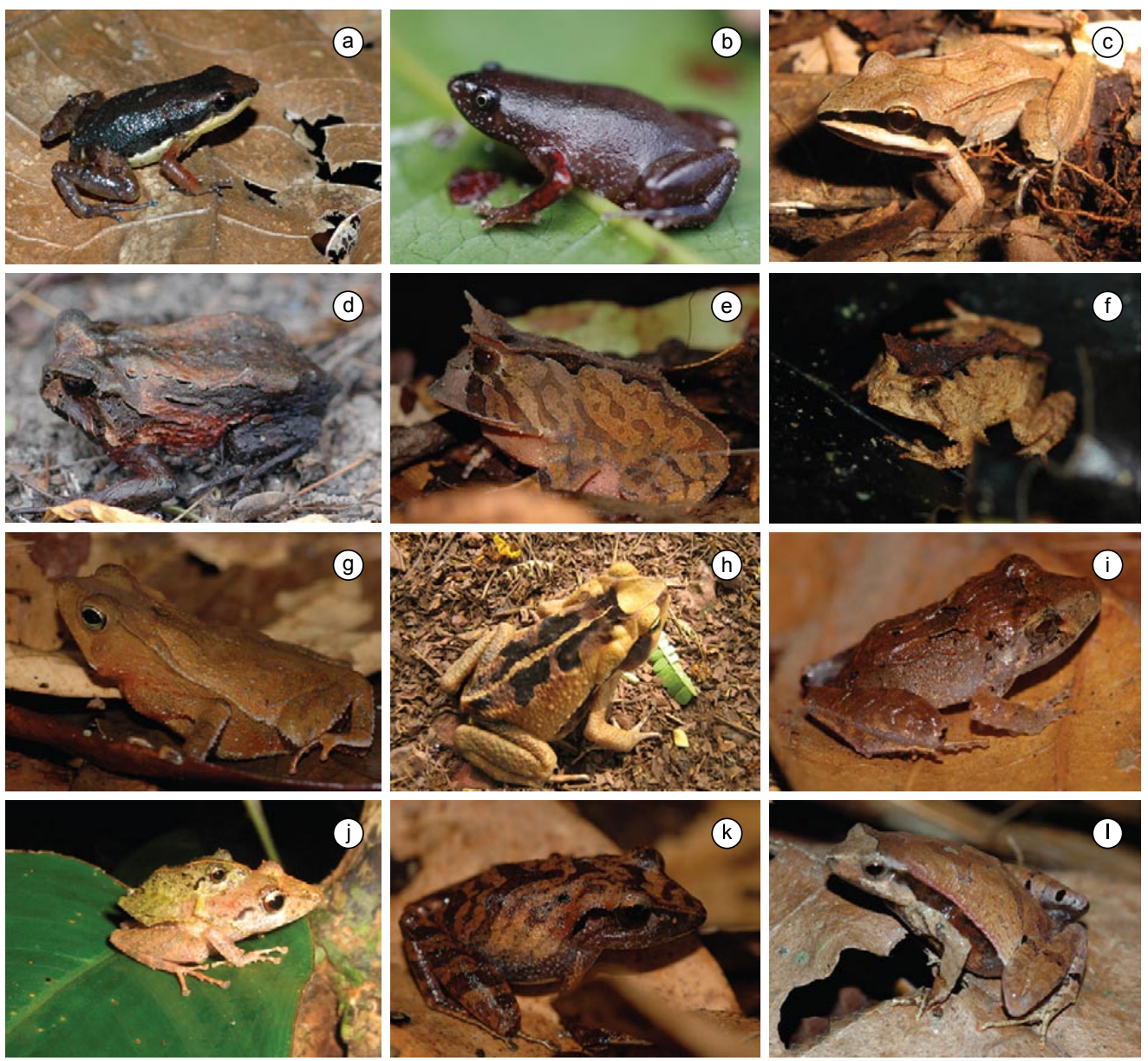

Figure 4. Anurans of the Reserva Ecológica da Michelin, Municipality of Igrapiúna, State of Bahia, Brazil. Aromobatidae: a) Allobates olfersioides; Microhylidae: b) Chiasmocleis cordeiroi; Leptodactylidae: c) Leptodactylus mystaceus; Cycloramphidae: d) Macrogenioglottus alipioi; e) Proceratophrys renalis; f) Proceratophrys schirchi. Bufonidae: g) Rhinella hoogmoedi; h) Rhinella crucifer. Craugastoridae: i) Haddadus binotatus. Brachycephalidae: j) Ischnocnema vinhai; k) Ischnocnema aff. ramagi; and 1) Physalaemus signifer.

sampled and on calling sites, only Dendropsophus branneri, D. elegans, Hypsiboas crepitans, Phyllomedusa burmeisteri, Scinax eurydice, S. $x$-signatus, and Leptodactylus latrans used more than one breeding site (temporary and permanent ponds). Species found breeding in streams were exclusive to this environment.

Some habitats and environments at the Reserva Ecológica da Michelin were not surveyed in this study (e.g. bamboo areas and canopy), or had a little sampling effort (bromeliads). Sampling effort standardization including such environments could increase anuran richness in this reserve.

Sixty seven percent of the species captured in the Reserva Ecológica da Michelin are currently categorized as "Least Concern" (LC), $17 \%$ as "Data Deficient" (DD), and $13 \%$ have their conservation status unknown (International... 2009, Table 1). Most LC species is highly tolerant to environmental degradation or is known by its success in several types of environments. Allobates olfersioides (Figure 4a) was the only species characterized as "Vulnerable" (VU: Verdade 2008) and Aplastodiscus cavicola (Figure 2a) as "Near Threatened" (NT; Cruz et al. 2004). Conservation status of both species was defined according to geographical distribution covering areas where habitat quality is threatened due to deforestation and agricultural development. Moreover, none of the species recorded in this study were listed as threatened by Ministério do Meio Ambiente (MMA) (Haddad 2008), although the method employed to define the species status conservation was the same used by IUCN (Haddad 2008).

Finally, a considerable percentage $(45.3 \%)$ of the species captured in the Reserva Ecológica da Michelin is endemic to the Atlantic Rain Forest, two of them previously known only from the type locality. Despite controversy between IUCN and MMA species frog conservation status, in this study one species was considered Vulnerable and another Near Threatened (International... 2009). These results emphasize the importance of these forest fragments for the preservation of Atlantic Rainforest frog species.

\section{Acknowledgements}

We are grateful to A. L. Xavier, J.P.S. Alves, I. Nunes, P. Lourenço, and R. Santos for their assistance in the fieldwork, Marcelo Nápoli and the other anonymous reviewer for additional helpful commentaries on the manuscript. Reserva Ecológica da Michelin for financial and logistic support; Instituto Brasileiro do Meio Ambiente e dos Recursos Naturais Renováveis (IBAMA) for the collection permit (Licença 030/07, IBAMA RAN processo 02010.000026/2007-49 and SISBIO ${ }^{\circ}$ 14299-1); Conselho Nacional de Desenvolvimento Científico e Tecnológico (Programa Institucional de Bolsas de Iniciação Científica/CNPq) and Fundação de Amparo à Pesquisa do Estado da Bahia (FAPESB) for fellowships to the first and second authors, respectively. 


\section{References}

AB'SÁBER, A.N. 1977. Os domínios morfoclimáticos na América do Sul: primeira aproximação. Geomorfologia 52:1-21.

BERNNETT, A.F., RADFORD, J.Q. \& HASLEM, A. 2006. Properties of land mosaics: Implications for nature conservation in agricultural environments. Biol. Conserv. 133(2):250-264.

BERTOLUCI, J. \& RODRIGUES, M.T. 2002. Utilização de habitats reprodutivos e micro-habitats de vocalização em uma taxocenose de anuros (Amphibia) na Mata Atlântica no sudeste do Brasil. Pap. Avulsos Zool. 42(11):287-297.

CARDOSO, A.J., ANDRADE, G.V. \& HADDAD, C.B.F. 1989. Distribuição espacial em comunidades de anfíbios (Anura) no sudeste do Brasil. Rev. Bras. Biol. 49(1):241-249.

CARNAVAL, A.C., HICKERSON, M.J., HADDAD, C.F.B., RODRIGUES, M.T. \& MORITZ, C. 2009. Stability predicts genetic diversity in the Brazilian Atlantic Forest hotspot. Science 323(5915):785-789.

CARVALHO-E-SILVA, S.P. \& TELLES, A.M. 2004. Dendropsophus giesleri. In IUCN Red List of Threatened Species (International Union for Conservation of Nature - IUCN). Version 2009.2. www.iucnredlist. org (último acesso em 13/12/2009).

CRUZ, C.A.G., CARVALHO-E-SILVA, S.P. \& PEIXOTO, O.L. 2004 Aplastodiscus cavicola. In IUCN Red List of Threatened Species (International Union for Conservation of Nature- IUCN). Version 2009.2. www.iucnredlist.org (último acesso em 13/12/2009).

DUELLMAN, W.E. \& TRUEB, L. 1986. Biology of Amphibian. Mc GrawHill, New York, 670p.

DUELLMAN, W.E. 1999. Global distribution of amphibians: Patterns, conservation, and future changes. The Johns Hopkins University Press, Baltimore, 633p.

HADDAD, C.F.B. \& PRADO, C.P.A. 2005. Reproductive modes in frogs and their unexpected diversity in the Atlantic Forest of Brazil. BioScience 55(3):207-217.

HADDAD, C.F.B. 2008. Uma análise da lista brasileira de anfíbios ameaçados de extinção. In Livro Vermelho da fauna brasileira ameaçada de extinção (A.B.M. Machado, G.M. Drummond \& A.P. Paglia, orgs.). Ministério do Meio Ambiente/Fundação Biodiversitas, Brasília, DF, p.287-295.

HADDAD, C.F.B., TOLEDO, L.F. \& PRADO, C.P.A. 2008. Anfíbios da Mata Atlântica: guia dos anfíbios anuros da Mata Atlântica. Ed. Neotropica, São Paulo. 244p.

International Union for Conservation of Nature and Natural Resources - IUCN 2009. IUCN Red List of Threatened Species. Cambridge. http://www. iucnredlist.org/ (último acesso em 15/05/2009).

JUNCÁ, F.A. \& PIMENTA, B. 2004. Ischnocnema bilineata. In IUCN Red List of Threatened Species (International Union for Conservation of Nature - IUCN). Version 2009.2. www.iucnredlist.org (último acesso em 13/12/2009).

LIMA, T.M. \& JUNCÁ, F.A. 2009. A herpetofauna de serrapilheira da reserva ecológica da Michelin, Ituberá, BAHIA, BRASIL. Sitientibus Ser. Cienc. Biol. 8(3-4):316-321.
MORELLATO, L.P.C. \& HADDAD, C.F.B. 2000. Introduction: The Brazilian Atlantic Forest. Biotropica 32(4):786-792.

MYERS, N., MITTERMEIER, R.A., MITTERMEIER, C.G., FONSECA, G.A.B. \& KENT, J. 2000. Biodiversity hotspots for conservation priorities. Nature 403(6772):853-858.

NAPOLI, F. \& PIMENTA, B.V.S. 2009. A new species of the Bokermannohyla circumdata group (Anura: Hylidae) from the coastal forests of Bahia, Northeastern Brazil. Copeia (4):674-683.

PEIXOTO, O. \& PIMENTA, B. 2004 OU 2009. Ischnocnema vinhai. In IUCN Red List of Threatened Species (International Union for Conservation of Nature - IUCN). Version 2009.2. www.iucnredlist.org (último acesso em 13/12/2009).

PIMENTA, B. \& JUNCÁ, F.A. 2004. Ischnocnema paulodutrai. In. IUCN Red List of Threatened Species. (International Union for Conservation of Nature - IUCN). Version 2009.2. www.iucnredlist.org (último acesso em: 13/12/2009).

PIMENTA, B.V.S., NAPOLI, M.F. \& HADDAD, C.F.B. 2009. New species of casque-headed tree frog, genus Aparasphenodon Miranda-Ribeiro (Amphibia: Anura: Hylidae), from the Atlantic Rainforest of Southern Bahia, Brazil. Zootaxa 2123:46-54.

PIMENTA, B.V.S., NUNES, I. \& CRUZ, C.A.G. 2007. Notes on the poorly known phyllomedusine frog Hylomantis aspera Peters, 1872 (Anura, Hylidae). South Am. J. of Herpetol. 2(3):206-214.

SANTOS, A.J. 2003. Estimativas de riqueza em espécies. In Métodos de estudos em biologia da conservação e manejo da vida silvestre (L. Cullen, R. Rudran Jr., \& C. Volladares-Padua, orgs). UFPR, Curitiba, p.19-41.

Secretaria do Planejamento do Estado da Bahia - SEPLAN. 2010. Territórios de identidade. http://www.seplan.ba.gov.br/mapa_territorios.html (último acesso em 23/02/2010).

SILVANO, D. \& PIMENTA, B. 2004. Hylomantis aspera. In IUCN 2009. IUCN Red List of Threatened Species (International Union for Conservation of Nature - IUCN). Version 2009.2. www.iucnredlist.org (último acesso em 13/12/2009).

SILVANO, D.L. \& PIMENTA, B.V.S. 2003. Diversidade de anfíbios na Mata Atlântica do Sul da Bahia. In Corredor de Biodiversidade na Mata Atlântica do Sul da Bahia (P.I. Prado, E.C. Landau, R.T. Moura, L.P.S Pinto, G.A.B. Fonseca \& K. Alger, orgs.). IESB, Ilhéus. 1 CD-ROM.

SILVANO, D.L. \& SEGALLA, M.V. 2005. Conservação de anfíbios no Brasil. Megadiversidade 1(1):79-86.

VERDADE, V. 2008. Allobates olfersioides. In Red List of Threatened Species (International Union for Conservation of Nature - IUCN). Version 2009.2. www.iucnredlist.org (último acesso em 13/12/2009).

WHITMORE, T.C. 1997. Tropical forest disturbance, disappearance, and species loss. In Tropical Forest Remnants, Ecology, Management, and Conservation of Fragmented Communities (W.F. Laurance \& R.O. Bierregaard, eds.). The University of Chicago Press, Chicago, p.3-12.

Received 13/11/09

Revised 24/05/10

Accepted 01/06/10 
Camurugi, F. et al.

\section{Appendix 1.}

Appendix 1. List of specimens captured at Reserva Ecológica da Michelin.

Allobates olfersioides: MZUEFS 3061; 3076; 3088-3089; 3103; 3591; 3633

Ischnocnema bilineata: MZUEFS 2954

Ischnocnema paulodutrai: MZUEFS 2840; 2841; 3596; 3597

Ischnocnema aff. ramagii : MZUEFS 2565; 2567; 2575; 2688; 2690; 2693; 2713; 2839; 2844; 2848; 2851; 2858-2859; 2951; 2993; 2955;

2957; 2959-2960; 2962; 2971; 3077; 3097; 3647

Ischnocnema vinhai: MZUEFS 3094-3096

Rhinella crucifer: MZUEFS 2568; 2570-2571; 2683; 2684; 2686-2687; 2689; 2694; 2736; 2942-2943; 2982; 3064-3067

Rhinella hoogmoedi: MZUEFS 2562-2563; 2566; 2577-2578; 2696-2698; 2701; 2704-2705; 2707; 2709; 2712; 2714; 2716-2717; 2719-2720; 2724; 2728-2732; 2822; 2829-2830; 2845; 2849; 2937-2941; 2969; 2977-2979; 2983-2984; $2988 ; 3075$

Haddadus binotatus: MZUEFS 2685; 2691; 2695; 2706; 2710; 2715; 2726-2727; 2733; 2836; 2843; 2846-2847; 2859-2864; 2916; 2947-2950; 2952; 2956; 2958; 2961; 2963-2965; 2970; 2972-2973; 2980; 2989; 3083; 3102; 3199; 3592; 3595; $3598 ; 3648$

Vitreorana sp: MZUEFS 822-824

Macrogenioglottus alipioi: MZUEFS 2946; 3185

Proceratophrys renalis: MZUEFS 2564; 2569; 2572; 2574; 2576; 2592; 2700; 2703; 2826-2828; 2830-2835; 2837-2838; 2842; 2852; 2857; 2933-2936; 2974-2976; 2981; 2986-2987; 3593-3594; 3599; 3646

Proceratophrys schirchi: MZUEFS 3578

Aplastodiscus cavicola: MZUEFS 2901

Aplastodiscus ibirapitanga: MZUEFS 2900

Aplastodiscus cf. sibilatus: MZUEFS 765-783

Bokermannohyla capra: MZUEFS 2879-2880; 3093; 3179-3180; 3631

Dendropsophus branneri: MZUEFS 2820; 2865-2873

Dendropsophus elegans: MZUEFS 2819; 2874-2878; 3082

Dendropsophus giesleri: MZUEFS 3174-3176

Dendropsophus haddadi: MZUEFS 2922-2926; 2928: 3166; 3183-3184; 3582-3586

Dendropsophus minutus: MZUEFS 3155; 3587; 3590

Dendropsophus seniculus: MZUEFS 3177-3178; 3588-3589

Dendropsophus sp.: MZUEFS 3182

Hylomantis aspera: MZUEFS 2917

Hypsiboas albomarginatus: MZUEFS 2897; 3072; 3100

Hypsiboas atlanticus: MZUEFS 2737; 2824; 2881

Hypsiboas crepitans: MZUEFS 3068-3069; 3079; 3090

Hypsiboas faber: MZUEFS 2896

Hypsiboas pombali: MZUEFS 2898-2899; 2920; 3101: 3156; 3644

Hypsiboas semilineatus: MZUEFS 3060; 3092

Phasmahyla timbo: MZUEFS 3632

Phyllodytes luteolus: MZUEFS 2931-2932; 3157

Phyllodytes melanomystax: MZUEFS 2906

Phyllomedusa burmeisteri: MZUEFS 2903-2905; 2080-3081

Phyllomedusa nordestina: MZUEFS 3073

Phyllomedusa rohdei: MZUEFS 2902; 2918; 3084; 3085-3086

Scinax strigilatus: MZUEFS 3063; 3181

Scinax eurydice: MZUEFS 3070-3071

Scinax aff. alter: MZUEFS 2818; 2821; 2823; 2882-2890

Scinax x-signatus: MZUEFS 2723; 2891-2895; 2914-2915: 3158-3162

Trachycephalus mesophaeus: MZUEFS 2919; 3104

Physalaemus signifer: MZUEFS 2573; 2708; 2725; 2734; 2929-2930; 3062; 3078; 3087; 3163-3165

Leptodactylus marmoratus: MZUEFS 2711; 3099

Leptodactylus mystaceus: MZUEFS 2722; 2944; 2966; 2985; 3074; 3098; 3198

Leptodactylus latrans: MZUEFS 2699; 2945

Chiasmocleis cordeiroi: MZUEFS 3167-3173

Chiasmocleis sp.: MZUEFS 3628-3631

Stereocyclops incrassatus: MZUEFS 2702 